\title{
SALES CAPABILITY AND PERFORMANCE: ROLE OF MARKET ORIENTATION, PERSONAL AND MANAGEMENT CAPABILITIES
}

\author{
GRAZIELA P. RODRIGUES ${ }^{1}$ \\ (iD) https://orcid.org/0000-0002-5840-9859 \\ TOMAS S. MARTINS \\ (iD) https://orcid.org/0000-0001-7355-7481
}

To cite this paper: Rodrigues, G. P., \& Martins, T. S. (2020). Sales capability and performance: Role of market orientation, personal and management capabilities. Revista de Administração Mackenzie, 21 (4), 1-29. doi:10.1590/1678-6971/eRAMR200199

Submission: Dec. 11, 2019. Acceptance: Mar. 12, 2020.

Federal University of Paraná (UFPR), Curitiba, PR, Brazil.

\section{(c) $\mathrm{BY}$}




\section{ABSTRACT}

Purpose: This article aims to explain the relationships between sales capabilities, which are split into personal selling and sales force management, both from the manager's point of view, and financial/customer performance in market-oriented firms.

Originality/value: This research is the first that explores in-depth sales capabilities and demonstrated that these capabilities need a previous strategic orientation. It checks different types of performance that can be the result of these two capabilities. We applied the research in to two types of companies, providing a number of contributions to the theory and practice of marketing.

Design/methodology/approach: We conducted a survey with 223 companies that were divided according to their activities: software/service developers and companies that only offer services in information technology and communication sector.

Findings: First, the two sales capabilities (personal and managerial) induce different performance, even when they are influenced by the same strategic orientation. Second, the mediation effect reinforces that sales force management capability is stronger than personal selling capability. Third, in service companies, it is important to develop personal selling capabilities. Lastly, they show that software/service companies present a differentiated behavior of service companies.

\section{KEYWORDS}

Sales capability. Personal selling. Sales force management. Market orientation. Organizational performance. 


\section{INTRODUCTION}

Sales activities are present in every company's routine, they have been seen as something ordinary, but in a more competitive and dynamic environment they present a series of challenges (Rodriguez, Ajjan, \& Peterson 2016). One of these challenges is acquiring and using essential market information in a strategic way to develop and increment sales activities (Narver \& Slater, 1990; Guenzi, Sajtos, \& Troilo, 2016).

We argue that a firm's set of sales capabilities is developed and adapted based on market information and knowledge. Sales capabilities can be understood from two points of view: sales management skills and the sales team itself. Personal selling capabilities are individual skills, they represent the overall salespeople's abilities with customers and managing customers' accounts. On the other hand, sales force management capabilities are related to all efforts needed to sell products or services in the marketplace, they include structuring the sales force across the organization, managing talents, and segmenting customers (Guenzi et al., 2016). In this study, sales capabilities are the combination of the sales management effort and the personal selling abilities of the team.

A firm that is committed to constantly develop its sales capabilities stack can not only achieve better short-term results, but also establish a more sustainable customer relationship strategy based on a broader value creation process (Rust, Ambler, Carpenter, Kumar, \& Srivastava 2004; Homburg, Vomberg, Enke, \& Grimm, 2015). We argue that understanding and developing sales capabilities based on a market information process can lead to better customer and financial performance. However, there is no clear understanding of how the information acquired and disseminated across the company is related to the development of sales capabilities from the sales team and management perspectives.

There are studies on different topics about sales capabilities that try to integrate marketing and sales or sales management (Homburg et al., 2015; Chen, Peng, \& Hung, 2015). However, the vast majority of these studies focus either on the individual (the salesperson) or the sales team (Wang \& Miao, 2015; Kumar, Sunder, \& Leone, 2013), but it is essential to understand and see sales capabilities as a broader process, one that seeks to build sustainable customer relationships (Guenzi et al., 2016). This perspective, which considers sales activities from a managerial and individual point of view, is relevant for business results, but it is still under-explored and needs further development (Sharma, 2016). 
In order to understand sales capability in detail, as a set of managerial and individual abilities, and the results generated by each of them, we propose an argument based on the relationships between market orientation, sales capabilities (personal selling and managerial capabilities) and financial/ customer performance. This paper presents sales capabilities in detail and verifies its mediating role in the relationship between market orientation and performance. Detailing sales capabilities and putting them in a mediating position of a classic relationship (market orientation and performance) allowed us to see which and in what context the bundle of certain sales capabilities affect performance in the short or long term, based on customer or financial performance.

This study focuses on B2B companies' market orientation and sales capabilities, because both generate results (Chang, 2014; Weitz \& Bradford, 1999), especially in competitive markets (Day, 1994), like that of the Brazilian information and communications technology (ICT) sector. Firms in this industry depend on their sales efforts to face this competitiveness (Brazilian Association of Information and Communications Technology Companies [Brasscom], 2016) and to effectively serve companies in other sectors that relay both on software and service solutions to be competitive (Brasscom, 2013).

Overall, this research presents four theoretical contributions. First, it shows that sales capabilities, as any other capability, are developed from a strategic orientation; we argue that market orientation drives sales capabilities in an individual and managerial way. These two sets of capabilities lead to different types of performance (customer or financial). Second, in general, sales force management capability has a greater impact on overall performance, when compared to personal abilities. Third, sales management capabilities influence personal selling capabilities in companies that sell services. Lastly, companies that sell software and services behave different, in terms of sales capabilities development and its relation to market orientation, when compared to companies that only sell services in the Brazilian ICT sector. This contribution shows that even companies in the same industry can have different results, therefore confirming resource-based vision (RBV) and Dynamic Capabilities arguments that performance is based on resources and the firm's environmental adaptive process (Barney, 1991; Teece, Pisano, \& Shuen, 1997). These two approaches are used on marketing capabilities and market orientation studies (Morgan, Vorhies, \& Mason, 2009; Ngo \& O'Cass, 2012; Krush, Agnihotri, Trainor, \& Nowlin, 2013; Narver \& Slater, 1990) that see the use of resources as a means to create and sustain value for the organization's stakeholders (Srivastava, Fahey, \& Christensen, 2001). 
The company's strategic focus, that is, its orientation, determines the development of specific capabilities and, therefore, generates different results.

In practical terms, this study generates four new practical implications for managers to allocate their sales resources more effectively both in the short and long term. First, the results will enable managers to invest in personal and/or managerial skills, depending on the results they are trying to achieve, that is, customer relationships or financial gains. Second, in general, our results show that it is important to invest in capabilities related to salesforce management regardless of the company's focus because this set of capabilities leads to better results. Third, companies that seek results based on customer relationship should invest more in sales activities based on the salesperson itself. Taking into account these two pieces of information, managers should attract the best sales talents and organize its sales force in a way that they could be more effective. Lastly, based on the company core, they can develop specific sales activities to obtain better results.

Therefore, this article is divided into four parts: theoretical background, method, e results, and conclusion.

\section{THEORETICAL BACKGROUND}

\subsection{Market orientation}

Market orientation is related to the development of the marketing concept. Deng and Dart (1994) argue that the marketing concept is a business philosophy, while market orientation is market intelligence that provides information to firms about how to create strategic responses to environmental opportunities.

Some approaches to market orientation suggest a definition of this strategic orientation. For Narver and Slater (1990), market orientation is generated by the organization's culture and is formed by three dimensions: customer, competition orientation, and cross-functional coordination, which correspond to activities that are involved in acquiring information about consumers and competitors. In addition, the cross-functional coordination uses the information to connect it to different internal departments' efforts to create superior value for the customer. Therefore, it focuses on the internal activities and processes developed across the functional areas.

A firm might take advantage of a business opportunity when all organizational members recognize that they can contribute to customer value creation. Market orientation is the one that will concentrate efforts and 
allow this to happen (Slater \& Narver, 1994). It allows better decisions to the competitive market, and it depends on the firm context (Noble, Sinha, \& Kumar, 2002; Guo, Wang, Hao, \& Saran, 2018). For Morgan and Vorhies (2018), market orientation has a central role in understanding the various objectives of an organization and in balancing the use of resources to achieve these objectives. In order to do so, a cultural component is necessary for market orientation to materialize in strategies and behaviors and attitudes related to responding or anticipating market needs and to obtain positive results related to consumers and competitors.

Ngo and O'Cass (2012) verified the role of other variables in explaining the relationship between market orientation and performance. They argue that market orientation is necessary. However, it is not enough. Other variables can explain this relationship because the firm needs to develop marketing strategies to create and demonstrate the value of its offerings to consumers, like organizational capabilities.

Mohiuddin Babu, Liu, Jayawardhena, and Dey (2019) verified the influence of employee orientation on converting the dimensions of marketing orientation into customer-based performance. They found a direct impact of the all market orientation dimensions on performance and, also, that employee orientation is a moderator only in the customer and competition orientation dimensions. The authors highlighted that they conducted the study in service firms in the UK and the implementation of market orientation should be explored in other countries combined with other resources.

A firm must understand the use and development of organizational capabilities to build and implement market knowledge (Morgan et al., 2009). These organizational capabilities, seen as skills developed by the company, can be driven by market orientation. In relation to sales activities, the sales team work generating market information. The information can be used to develop management and customer relationship activities (Day, 1994; Morgan, 2012). Market orientation will mount the development of sales skills that may turn into unique, difficult to imitate, rare, valuable and nonreplaceable resources (Barney, 1991). Understanding the use of these resources helps the company to create and sustain value for the organization's stakeholders (Srivastava et al., 2001). So, we propose that market orientation influenced sales capabilities.

\subsection{Sales capabilities}

There are few recent studies focusing on sales capabilities, such as Krush et al. (2013), who studied this capability and firm performance in 
marketing dashboards and sensemaking. Siahtiri, O’Cass, and Ngo (2014) studied marketing capabilities and sales capabilities on customer-centric performance and brand performance in the B2B market. Finally, Guenzi et al. (2016) developed a model to measure sales capabilities.

According to Krush et al. (2013), the sales capability and marketing dashboards' efforts of a business unit directly and positively influence its sensemaking. Sales capability works acquiring customer information (Vorhies \& Morgan, 2005) that, when used with marketing dashboards, which are a technology that allows access to important marketing metrics and initiatives (Krauss, 2005), help companies to construct market knowledge (Krush et al., 2013).

Siahtiri et al. (2014) results show that marketing and sales capabilities are critical to customer-centric performance, which generates an increase in $\mathrm{B} 2 \mathrm{~B}$ brand performance. Based on these results, the authors suggest that the marketing and sales units are complementary and are the main capabilities responsible for brand performance in $\mathrm{B} 2 \mathrm{~B}$ organizations.

Guenzi et al. (2016) proposed a new model because they saw that previous research on sales capabilities did not represent the entire sales process. So, they proposed that sales capabilities are divided into personal selling and sales force management. This occurs because the sales activities are embedded in a process that includes the skills of the individuals that are part of a team and the management of the whole sales efforts. Salespeople focus on customer relationship, so they develop individual skills to better relate to customers. Their activities are supervised and result in a certain type of performance. On the other hand, sales force management capability aims to structure the sales force, manage talents and segment the customers. The result of this management work is different from the result presented by the salespeople's focus.

Sales capabilities, as a kind of marketing capability, can be developed from strategic orientations (Day, 1994; Morgan et al., 2009). The market orientation with a cultural approach develops market knowledge based on customers' and competitors' information (Narver \& Slater, 1990). The salespeople use this information as a resource to develop individual skills (Guo et al., 2018; Mohiuddin Babu et al., 2019), which include personal selling capabilities (Guenzi et al., 2016). We propose:

- H1: Market orientation positively influences personal selling capabilities.

Besides the personal selling capability, sales capabilities are organizational resources that also focus on organizing and managing the sales efforts 
to build customer relationships (Guenzi et al., 2016). Therefore, we can see that market orientation should also influence the managerial aspect of sales as a resource, which is the basis for the following hypothesis:

- H2: Market orientation positively influences sales force management capabilities.

\subsection{Sales capabilities and performance}

There are many studies that show the relationship between marketing capabilities and performance (Vorhies \& Morgan, 2005; Ngo \& O'Cass, 2012). There is no consensus about the type of performance these capabilities contribute to, but there are some more frequent measures used: sales growth, market share, profitability and customer satisfaction (Morgan, 2012; Guenzi et al., 2016).

Recent studies that focus only on sales capabilities rank performance in different ways, Guenzi et al. (2016), for example, they argue that sales activities contribute to customer performance (customer satisfaction and loyalty), market performance (market share and revenue growth) and financial performance (profitability). Siahtiri et al. (2014) demonstrated that sales and marketing capabilities contribute to customer-centric performance and B2B brand performance.

Sales capabilities, as a marketing capability, contribute to organizational performance (Morgan, 2012; Ngo \& O'Cass, 2012). However, these capabilities probably generate different results. We divided performance into two dimensions: customer and financial. This division was made to set a difference in terms of what we consider short-term or long-term performance. Based on Rust et al. (2004), performance should be evaluated in a financial and non-financial way. Our argument is that personal selling capabilities focus on long-term relationships with customers that do not necessarily generate a short-term financial result.

Personal selling capability is a process that incorporates both the ability to sell and to develop customer relationships through account management. In order to manage accounts, it is necessary to develop sales and interpersonal skills (Rentz, Shepherd, Tashchian, Dabholkar, \& Ladd, 2002). Customers expect salespeople to deliver products and services that have a higher added-value, and, because of this expectation, many organizations focus on developing sales abilities that generate a relationship with customers (Weitz \& Bradford, 1999). Thus, salespeople must have communication and sales presentation skills, knowledge of the product or service, and develop activities 
with customers (Rentz et al., 2002). Salespeople are performing sales activities daily with customers when they focus on long-term relationships. To establish this relationship, we argue that customer performance is related to attraction, retention, satisfaction and customer loyalty (Guenzi et al., 2016; Ngo \& O'Cass, 2012). In sum, salespeople will naturally help the firm improve customer performance (Baldauf, Cravens, \& Piercy, 2001; Rentz et al., 2002; Siahtiri et al., 2014):

- H3: Personal selling capabilities positively influence customer performance.

Salesforce management capabilities emphasize short-term results, mainly financial outcomes. Even though it is focused on financial results, the company cannot ignore the market elements, that is, environment and competitors' characteristics that collaborate with marketing productivity (Rust et al., 2004).

Salesforce management capability encompasses broader processes, ranging from talent attraction to market segmentation (Guenzi et al., 2016). Sales management is seen as the extension of monitoring, targeting, evaluating and rewarding of sales activities, which are carried out by the sales force (Anderson \& Oliver, 1987). The sales manager is responsible for the strategic choices that are reflected in the sales team behaviors. It is important because it directs sales activities according to the strategic orientation adopted by the organization and the company context (Baldauf et al., 2001; Siguaw, Brown, \& Widing, 1994).

The context, the company and the market characteristics define salesforce structuring, which includes the size and the team organization to operate in the market (Zoltners, Sinha, \& Lorimer, 2008). Besides structuring the sales force and managing talents, it is necessary to allocate resources and sales efforts in products and markets, that is, to have the ability to segment this market and to act on with the sales force in an effective way (Guenzi et al., 2016).

The management capability directs sales force activities, such as salespeople training, planning, as well as talent management and other activities that make the sales team reach highest financial returns. So, the management is more concerned with financial performance than with customer relationships (Baldauf et al., 2001) and one of the challenges of sales force management is to ensure financial performance, verifying how to achieve better results and considering market environment and competitors (Rust et al., 2004; Zoltners et al., 2008): 
- H4: Salesforce management capabilities positively influence financial performance.

\subsection{Salesforce management and personal selling capability}

The sales capability is a process for the relationship building with customers (Siguaw et al., 1994). In Guenzi et al.'s (2016) framework, sales capabilities are divided into personal selling capability, whose focus is mainly on processes performed by salespeople and account management; and, sales force management capability, which includes manager activities like attracting talents to the sales force and market segmentation. So, it precedes personal selling capability. Sales management directs the sales force to ensure team member performance (Baldauf et al., 2001; Siguaw et al., 1994). In addition, the management uses market information to develop activities that positively influence individual abilities. Thus, it is proposed:

- H5: Salesforce management capability positively influences personal selling capabilities.

\subsection{Market orientation, sales capabilities and performance}

Sales capabilities are developed from a strategic orientation (Morgan et al., 2009), and both influence organizational performance (customers and financial) (Baldauf et al., 2001; Zoltners et al., 2008). Therefore, it can be said that sales capabilities play a mediating role in the relationship between market orientation and organizational performance.

Sales capabilities should contribute to positive results for more marketoriented firms. They tend to work better internally, across different department areas, with information obtained in the external environment with customers and competitors. A market orientation with a cultural approach (Narver \& Slater, 1990) influences the development of sales capabilities because they actually happen with market knowledge. These capabilities operate in the organization's border when relating to customers and competitors (Day, 1994; Siguaw et al., 1994), and, thus, this general ability to sell influences firms' results.

Marketing capabilities generally play a mediating role in studies that relate market orientation and performance (Smirnova, Naudé, Henneberg, Mouzas, \& Kouchtch, 2011; Ngo \& O'Cass, 2012). Some articles, besides showing the mediating role of marketing capabilities, relate market orientation to some specific sales activities (Wang \& Miao, 2015; Lengler, Sousa, \& 
Marques, 2013), but it is still necessary to understand which capabilities related to market orientation contribute to superior performance (Kirca, Jayachandran, \& Bearden 2005; Morgan et al., 2009; Mohiuddin Babu et al., 2019). As sales capabilities are a marketing capability (Morgan, 2012), one can say that they play this mediating role. This study aims to understand the process through which market orientation is related to a specific marketing capability, i.e. sales capabilities contribute to superior performance (Kirca et al., 2005), both in short and long-term (Baldauf et al., 2001; Zoltners et al., 2008).

The personal selling capability generates results with customers, and focus in a long-term relationship (Baldauf et al., 2001); this capability is influenced by market orientation (Morgan et al., 2009) that generates precise information about the clients (Narver \& Slater, 1990). It is necessary to develop a capability to manage the information collected in the market and, after working with it, effective customer performance can be generated:

- H6: The relationship between market orientation and customer performance is mediated by personal selling capability.

The management aims to ensure sales force performance, mostly the financial results (Anderson \& Oliver, 1987; Baldauf et al., 2001). This management certainly uses market information, from customers and competitors, and also works with internal processes to make decisions on how to allocate resources (Morgan et al., 2009; Narver \& Slater, 1990) in order to guarantee sales force performance posteriorly, as a result:

- H7: The relationship between market orientation and financial performance is mediated by sales force management capability.

Figure 2.5.1 represents the proposed model with the concepts presented and the relationships between them. 


\section{(Figure 2.5.1)}

\section{THEORETICAL MODEL}

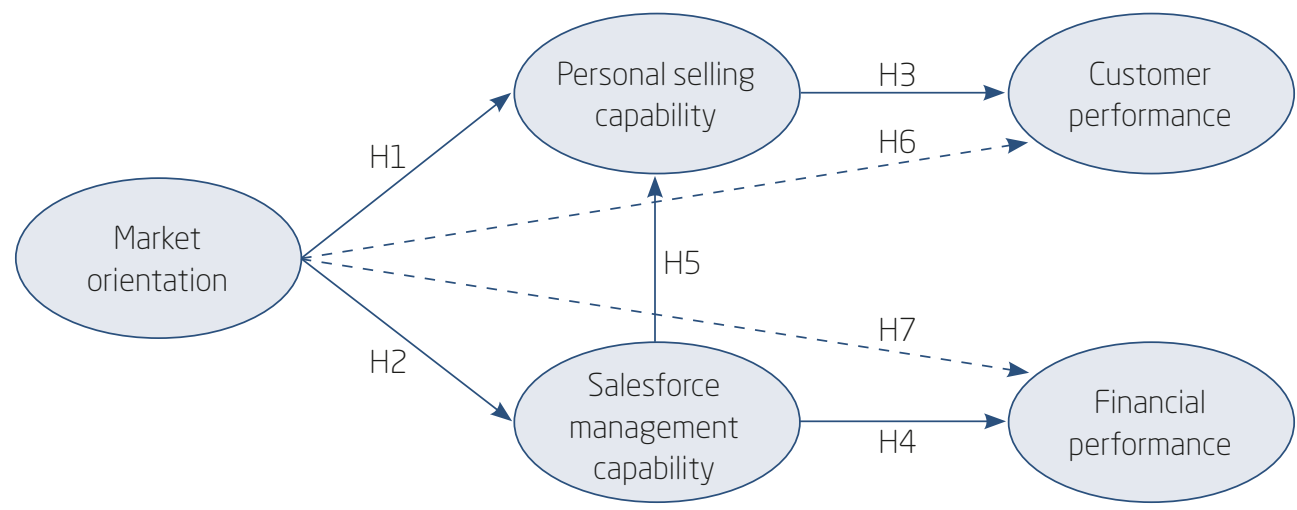

Source: Elaborated by the authors.

\section{METHOD}

\subsection{Sample and data collection}

We ran a survey with ICT companies in Brazil. Sales activities become more relevant in this sector because these companies develop software solutions and sell additional services with these solutions for all industries (Brasscom, 2016).

A first questionnaire was carried out with one salesperson and two marketing/sales managers. The final items of this questionnaire were selected after professionals in the area validated them.

Data collection lasted three months. The questionnaire was sent by e-mail to the companies; the respondents were able then to access a link to participate in the survey. We first sent 356 emails, with a return rate of $24.2 \%$, resulting in 86 cases. Other respondents were asked to respond personally using a smartphone or tablet in meetings and major events in the area, so we gathered 166 more cases.

The respondents are mostly owners (37\%), sales managers (20\%), marketing managers $(8 \%)$, managers of other areas $(14 \%)$ who are engaged in day-to-day marketing and sales activities. They are salespeople (9\%) or they have positions in companies related to marketing and sales management activities (12\%). Despite having a manager perspective, we included salespeople and business owners, because small Brazilian companies do not 
always have a structured sales sector. Sometimes the salesperson takes on the management role.

The final sample had 223 software and services companies since 25 cases were discarded because they did not meet the expected profile. Eleven respondents did not work in the sector, ten were not involved in the activities of the marketing and sales areas. Finally, four more cases were eliminated because they were hardware companies. The sample size is adequate, the minimum size of 89 was calculated by the G-Power software. The parameters used were: effect size $\left(f^{2}=0.15\right)$, statistic power $=95 \%$, significance level $=5 \%$ and number of predictors $=1$ (Hair, Hult, Ringle, Sarstedt, \& Thiele, 2017).

Most companies (78.5\%) are software developers and sell additional services; these companies were gathered in group 1. Group $2(21.5 \%)$ are service companies. We consider that, depending on the focus of the company, these relations can behave differently. For example, a company that sells software solutions and additional services may emphasize one set of sales capabilities that are different from companies that only offer ICT services. Firms that have a service focus, generally do marketing activities thinking more about people than about productive processes. They focus on long-term relationships, customer service quality, and negotiations transparency, even though the services in our paper are based on products (Lusch \& Vargo, 2006).

\subsection{Constructs measurement}

The questionnaire was constructed based on existing scales in the literature. For the market orientation, we adapted Narver and Slater's (1990) scale with 12 indicators. After exploratory factorial analysis, three items were removed, because these items did not affect the research objective. For the sales capabilities, we used Guenzi et al.'s (2016) scale, with five items for personal selling capability and eight items for sales force management capability.

The performance scale with customers contained two indicators from Guenzi et al.'s (2016) and three indicators from the Ngo and O'Cass' scale (2012); these were used to demonstrate the long-term relationship with customers and the non-financial outputs (Rust et al., 2004). Financial performance was measured through Cruz-González, López-Sáez, NavasLópez, and Delgado-Verde (2015), with six items, along with three indicators from Guenzi et al. (2016). These adapted performance scales are consolidated 
in the literature to measure financial outcomes, but it was chosen to add the indicators used in the study by Guenzi et al. (2016). These indicators demonstrated the impact of the market environment on marketing performance in the short-term (Rust et al., 2004).

The final questionnaire, then, had 42 questions, all of which were measured using a ten point Likert scale, ranging from 1 (strongly disagree) to 10 (totally agree) or 1 (much worse than competitors) to 10 (much better than competitors).

\section{RESULTS}

Before testing the hypothesizes, data normality and outlier evaluation tests were performed. The Kolmogorov-Smirnov's test presented a p-value $>0.05$, which is a non-normal distribution. Four outliers were eliminated because they were considered "extreme" in the Boxplots test in the SPSS software (Hair Jr., Hult, Ringle, \& Sarstedt, 2014).

For data treatment, residual graphs in the SPSS were analyzed to verify linearity and homoscedasticity. We ran a multiple regression with data randomly distributed around zero and in a linear form. To verify multicollinearity, we analyzed the tolerance and variance inflation factor (VIF) indicators. All tolerance indicators presented values $>0.1$, that is, there was no collinearity. Likewise, the VIF values were less than 5 (Pallant, 2013). Singularity occurs when the variables are redundant, that is, one variable is a combination of other variables (Tabachnick \& Fidell, 2013). It does not occur in the proposed model. In sum, we concluded the absence of multicollinearity and singularity.

The exploratory factor analysis was performed for each construct. In all constructs, the Kaiser-Meyer-Olkin (KMO) was above 0.7 and significant $(p=0.00)$. Only in the market orientation variable, three items were removed, with commonality below 0.4 . Then, the reliability test was performed, which showed adequate values because they are greater than 0.7 (Hair Jr et al., 2014).

For hypothesis testing, confirmatory factor analysis was performed in the SmartPLS software. The first item analyzed was the outer loading, which was significant, that is, above 0.7 (Hair Jr. et al., 2014). Some items presented values between 0.4 and 0.7 , and these were considered acceptable because they did not affect the constructs convergent validity since the average extracted validity (AVE) was above 0.50 (Hair Jr. et al., 2014). The constructs presented convergent validity. 


\section{(Figure 4.1)}

CONVERGENT VALIDITY

\begin{tabular}{lccccc}
\hline & AVE & CR & R & R² adjusted & Cronbach's alpha \\
\hline Market orientation & & & & Group 1 & \\
\hline Salesforce management capability & 0.60 & 0.92 & 0.49 & 0.48 & 0.91 \\
\hline Personal selling capability & 0.65 & 0.90 & 0.38 & 0.35 & 0.90 \\
\hline Customer performance & 0.62 & 0.89 & 0.46 & 0.43 & 0.86 \\
\hline Financial performance & 0.75 & 0.96 & 0.62 & 0.60 & 0.85 \\
\hline & & & & Group 2 & \\
\hline Market orientation & 0.51 & 0.92 & - & - & 0.91 \\
\hline Salesforce management capability & 0.61 & 0.93 & 0.45 & 0.45 & 0.91 \\
\hline Personal selling capability & 0.67 & 0.91 & 0.58 & 0.58 & 0.87 \\
\hline Customer performance & 0.60 & 0.88 & 0.44 & 0.43 & 0.83 \\
\hline Financial performance & 0.76 & 0.97 & 0.52 & 0.52 & 0.96 \\
\hline
\end{tabular}

Source: Elaborated by the authors.

The constructs presented discriminant validity according to the Fornell and Larcker (1981) criteria.

(Figure 4.2)

\section{DISCRIMINANT VALIDITY}

\begin{tabular}{|c|c|c|c|c|c|}
\hline & $\begin{array}{c}\text { Customer } \\
\text { performance }\end{array}$ & $\begin{array}{l}\text { Financial } \\
\text { performance }\end{array}$ & $\begin{array}{c}\text { Market } \\
\text { orientation }\end{array}$ & $\begin{array}{l}\text { Personal } \\
\text { selling } \\
\text { capability }\end{array}$ & $\begin{array}{c}\text { Salesforce } \\
\text { management } \\
\text { capability }\end{array}$ \\
\hline & \multicolumn{5}{|c|}{ Group 1} \\
\hline Customer performance & 0.785 & & & & \\
\hline Financial performance & 0.748 & 0.867 & & & \\
\hline Market orientation & 0.674 & 0.576 & 0.722 & & \\
\hline Personal selling capability & 0.553 & 0.534 & 0.580 & 0.807 & \\
\hline $\begin{array}{l}\text { Sales force management } \\
\text { capability }\end{array}$ & 0.630 & 0.778 & 0.700 & 0.549 & 0.777 \\
\hline
\end{tabular}




\section{(Figure 4.2 (conclusion))}

DISCRIMINANT VALIDITY

\begin{tabular}{llllll}
\hline & $\begin{array}{c}\text { Customer } \\
\text { performance }\end{array}$ & $\begin{array}{c}\text { Financial } \\
\text { performance }\end{array}$ & $\begin{array}{c}\text { Market } \\
\text { orientation }\end{array}$ & $\begin{array}{c}\text { Personal } \\
\text { selling } \\
\text { capability }\end{array}$ & $\begin{array}{c}\text { Salesforce } \\
\text { management } \\
\text { capability }\end{array}$ \\
\hline Customer performance & 0.776 & & Group 2 & \\
\hline Financial performance & 0.615 & 0.873 & & & \\
\hline Market orientation & 0.689 & 0.459 & 0.714 & 0.816 & \\
\hline Personal selling capability & 0.608 & 0.537 & 0.653 & 0.783 \\
\hline $\begin{array}{l}\text { Salesforce management } \\
\text { capability }\end{array}$ & 0.623 & 0.724 & 0.675 & 0.733 & \\
\hline
\end{tabular}

Source: Elaborated by the authors.

Additionally, the Harman one-factor test was done to show that the model did not present common methods bias $(44,3 \%)$, the value was less than $50 \%$.

The hypotheses test was performed with a structural equation model. To verify hypotheses significance, the bootstrapping test was performed, in which the $t$ value for a significance of $95 \%(\mathrm{p}<0.05)$ was used (Hair Jr. et al., 2014).

\section{(Figure 4.3)}

\section{HYPOTHESIS TEST}

\begin{tabular}{lcccccr}
\hline & \multicolumn{3}{c}{ Group 1 } & & Group 2 & \\
\hline \multicolumn{1}{c}{ Hypothesis } & $\begin{array}{c}\text { Path } \\
\text { coefficient } \\
(\beta)\end{array}$ & p-value & Result & $\begin{array}{c}\text { Path } \\
\text { coefficient } \\
(\beta)\end{array}$ & p-value & Result \\
\hline $\begin{array}{l}\text { H1: Market orientation > } \\
\text { personal selling capability }\end{array}$ & 0.38 & 0.049 & Supported & 0.28 & 0.000 & Supported \\
\hline $\begin{array}{l}\text { HZ: Market orientation > } \\
\text { sales force management } \\
\text { capability }\end{array}$ & 0.70 & 0.000 & Supported & 0.67 & 0.000 & Supported \\
\hline $\begin{array}{l}\text { H3: Personal selling } \\
\text { capability > customer } \\
\text { performance }\end{array}$ & 0.27 & 0.098 & $\begin{array}{c}\text { Not } \\
\text { supported }\end{array}$ & 0.33 & 0.001 & Supported \\
\hline
\end{tabular}




\section{(Figure 4.3 (conclusion))}

\section{HYPOTHESIS TEST}

\begin{tabular}{|c|c|c|c|c|c|c|}
\hline \multirow[b]{2}{*}{ Hypothesis } & \multicolumn{3}{|c|}{ Group 1} & \multicolumn{3}{|c|}{ Group 2} \\
\hline & $\begin{array}{l}\text { Path } \\
\text { coefficient } \\
(\beta)\end{array}$ & p-value & Result & $\begin{array}{l}\text { Path } \\
\text { coefficient } \\
(\beta)\end{array}$ & $\mathrm{p}$-value & Result \\
\hline $\begin{array}{l}\text { H4: Salesforce } \\
\text { management capability > } \\
\text { financial performance }\end{array}$ & 0.69 & 0.000 & Supported & 0.72 & 0.000 & Supported \\
\hline $\begin{array}{l}\text { H5: Salesforce } \\
\text { management capability > } \\
\text { personal selling capability }\end{array}$ & 0.29 & 0.126 & $\begin{array}{c}\text { Not } \\
\text { supported }\end{array}$ & 0.55 & 0.000 & Supported \\
\hline $\begin{array}{l}\text { Indirect effect: } \\
\text { H6: Market orientation > } \\
\text { personal selling capability } \\
\text { > customer performance }\end{array}$ & 0.11 & 0.321 & $\begin{array}{c}\text { Not } \\
\text { supported }\end{array}$ & 0.09 & 0.025 & Supported \\
\hline $\begin{array}{l}\text { Indirect effect: } \\
\text { H7: Market orientation > } \\
\text { sales force management } \\
\text { capability > financial } \\
\text { performance }\end{array}$ & 0.48 & 0.001 & Supported & 0.48 & 0.000 & Supported \\
\hline
\end{tabular}

\section{Source: Elaborated by the authors.}

Hypothesis 1 was supported (group 1: $\beta=0.38$; group 2: $\beta=0.28$ ). Showing that market orientation has a direct and positive impact on personal selling capability. Hypothesis 2 was significant (group 1: $\beta=0.70$; group 2: $\beta=0.67$ ) too.

The influence of personal selling capability on customer performance (H3) occurs only in group $2(\beta=0.328)$. Hypothesis 4 points out that sales force management capability have a strong and significant impact on financial performance (group 1: $\beta=0.69$; group $2: \beta=0.72$ ).

The results of hypothesis 5 show the influence of sales force management capabilities on personal selling capability only in group $2(\beta=0.55)$.

Hypothesis 6 shows that market orientation has an indirect effect on customer performance through personal selling capability only in group 2 $(\beta=0.09)$. Hypothesis 7 presented an effect in both groups (group $1: \beta=$ 0.48 ; group 2: $\beta=0.48$ ).

\subsection{Results discussion}

This research contributes to the literature, since it presents the differences between personal selling and sales force management capabilities, even 
when these capabilities are influenced by the same strategic orientation. The results show that it exerts a different influence on performance, depending on the focus of the sales activities (individual or managerial). It is also different depending on the type of company analyzed, software/services or services only.

This research presents sales capabilities details when it is divided into two, differently from the original model, proposed by Guenzi et al. (2016). This way, we were able to reinforce that a marketing capability, such as sales capabilities, can be divided into smaller bundles, helping the general understanding of a global concept. As a result, we can say that this study focuses on the two most specific aspects of the sales capabilities, adding to the literature a view that there might be two different kinds of sales capabilities, one that is related to the team and the management of the team and another one related to a more strategic aspect, that is setting up the sales process.

Hypothesis 1 and 2 present that market orientation has a greater impact on the sales force management capability compared to personal selling capability. In group 2, this difference is even greater. One explanation is that the sales team management is responsible for the strategic choices that are reflected in sales team behaviors (Baldauf et al., 2001). These choices are made based on the market information generated and are aimed at guaranteeing the sales performance (Zoltners et al., 2008).

The greater difference in group 2 is due to the very nature of service delivery. Services are combined with products to meet a specific customer need, but only custom solutions are truly effective for a company to create a competitive advantage (Sharma \& Iyer, 2011). Thus, companies that sell the same software solution need to differentiate themselves through services, i.e., they need to manage their sales force to help them innovate their services (Miles, 2005; Trott, 2008).

The research presents a theoretical contribution when it shows the impact of marketing capabilities on performance. It is not as generalist as previous studies (Vorhies \& Morgan, 2005; Morgan et al., 2009). We show the difference between sales capabilities (personal selling and sales force management) when analyzing its impact on different types of performance. This influence showed different behaviors when studied separately (H3 and H4).

Hypothesis 3 is significant only in service companies. These companies need to maintain a close relationship with customers. Personal selling capability is an ability to maintain this relationship with customers, either by the seller's ability or by account management. Consequently, it has a greater contribution to customer performance. In the B2B context, the long-term 
relationship is very important to firms, so it is necessary for sales activities to maintain it (Homburg et al., 2015).

Hypothesis 4 shows the influence of management skills on financial performance. As the management aims to guarantee the performance of the sales team, they usually present the financial metrics to defend the budget and, thus, obtain support from the top management for investments (Baldauf et al., 2001; Homburg et al., 2015).

Based on the results presented, sales capabilities had a greater impact on group 2. Therefore, the development of sales capabilities in this group effectively contributes to firm results.

Group 1, in addition to developing a product, needs to show this product to their customers as a business solution (Sawhney, 2006), but the results show a contradictory fact. These companies develop individual skills, but personal selling does not contribute to customer performance. In group 2, managerial and individual capabilities impacted performance. So, these companies need to innovate when providing services (Trott, 2008). A service company needs to maintain a closer relationship with customers (Homburg et al., 2015), which demonstrates that personal selling capability impacts on customer performance.

The second contribution is the result of the mediation test. The results reinforce that sales force management capabilities have a greater impact on performance in the ICT sector. However, this research is different from previous studies (Guenzi et al., 2016), when it shows that sales capabilities need prior strategic orientation, such as market orientation.

Market orientation had an indirect effect on financial performance through sales force management capability in both groups (H7). Personal selling capability has a mediating effect on the relationship between market orientation and customer performance only in group 2, however, with a weak effect. The result is unexpected for service companies since they tend to increase sales based on customer relationship activities and, thus, to be more capable in terms of personal selling. Service companies grew $7.5 \%$ in terms of gross revenue in Brazil since the expansion of the software market requires more maintenance, support and consulting (Brasscom, 2016).

The results of $\mathrm{H} 5$ provide the third contribution. Similarly to $\mathrm{H} 3, \mathrm{H} 5$ shows a positive influence only in group 2 . These results reinforce the need to develop the sales force because service companies need to develop longterm relationships with customers (Homburg et al., 2015). H4 results not only reinforce Guenzi et al.'s scale (2016) framework, but also expand it, when showing the details applied in different groups. In group 1, which has 
its focus on the software, we can say that it is more similar to selling a product; and services are a way to differentiate their software. If we see the software as a product, its sales depends much less on the salesperson's relationship ability with the customers and much more on the managerial skills of the firm, therefore, more focused on the financial result.

Lastly, this division of sales capability provided a more in-depth division when analyzed in types of companies. In both groups, the development of managerial skills, when influenced by the market orientation, contributes to financial performance. ICT companies need to offer more than one product or service to gain competitive advantage, that is, it is necessary to propose a solution for customers according to their expectations (Sawhney, 2006; Sharma \& Iyer, 2011). It is essential for these companies to develop activities with managers to obtain financial results ( $\mathrm{H} 4$ and $\mathrm{H} 7)$.

In service companies, the management activities can provide better results too. They need to develop managerial activities because service innovation demands well-managed processes (Miles, 2005). However, it is also necessary to develop personal selling capability in order to obtain customer performance ( $\mathrm{H} 3$ and $\mathrm{H} 6$ ). The management itself helps in the development of this capability (H5).

The discussion presented allowed us to explore the concept of market orientation and sales capabilities in greater depth, as well as to verify different sales activities outcomes in Brazilian ICT companies, divided into two groups.

\section{THEORETICAL CONTRIBUTIONS}

This research leads us to four theoretical contributions. First, the result demonstrates that sales capability needs a prior strategic orientation. So, the perspective that splits sales activities into two (personal selling and sales force management) is reinforced (Guenzi et al., 2016; Sharma, 2016), and also explains the activities that develop each of these abilities. This fact complements recent studies on sales capabilities (Krush et al., 2013; Siahtiri et al., 2014). This perspective still shows that the impact of a company's specific capability on performance is not as generic as the previous studies in the marketing area (Vorhies \& Morgan, 2005; Ngo \& O'Cass, 2012). This fact shows the need to carry out more studies about specific capabilities in companies in certain contexts, such as the ITC industry in an emerging economy, such as Brazil.

Second, the results of sales force management capability mediation reinforce the importance of management in the context studied. This fact 
indicates that, when looking for a financial result, in the short term, it is necessary to develop management capability. However, service companies need to focus more on the development of personal selling capabilities since their long-term relationships should be their focus.

Third, this research demonstrates that sales force management capability develops personal selling capability in service companies. In this way, it reinforces the previous findings of sales capability (Guenzi et al., 2016) and also complements it, showing that it is necessary to better understand this relationship in each company type.

Finally, our model in different types of company reinforces the fact that the sales capabilities are specific and must be studied separately. This occurs because different capabilities (individual and managerial) affect two types of companies differently.

In sum, this study provided a better understanding of market orientation impacts on organizational performance through a specific marketing capability, presenting that a more in-depth understanding of a specific activity contributes to a more general understanding of organizational capabilities (Morgan, 2012). This fact reinforces the importance of sales activities on organizational performance, as well as the integration of sales with marketing activities.

\section{MANAGERIAL IMPLICATIONS}

This study provides four managerial implications. Firstly, ICT managers are able to identify what activities need investment, in terms of individual or managerial capabilities to reach different performances with customers in the long run (Homburg et al., 2015), or even more financially oriented in the short-term (Baldauf et al., 2001). These results are also different, depending on the company's focus. It is important to emphasize that these activities are impacted by the company's strategic guidelines, in this case, with its cultural approach (Narver \& Slater, 1990). Understanding the strategic direction will help managers to develop capabilities.

Secondly, the development of a sales force management capability is paramount since it has a greater return in the analyzed context (Guenzi et al., 2016). The activities with customers and competitors in the market are also more effective in developing more management capabilities when compared to the individual skills of the sales team. In this way, managers can allocate sales talents in the best manner; because of that, they can improve company 
results, as well as provide the best working conditions in an effective manner. As a consequence, these activities cause an economic and commercial impact on ICT companies, with financial and market results (Rust et al., 2004).

The third contribution for practitioners is that managers should invest in personal selling capability only in service companies. If the service managers are looking for financial performance, in both company types, they have the option of investing in management activities. For example, these activities are segmenting and selecting the appropriate selling model for each customer, and they provide this information to the sales force. Managers can contribute to attract and retain the best talent and provide the team with the correct opportunities to be an effective salesperson (Guenzi et al., 2016).

Finally, managers need to identify their type of company, even in the same industry, in order to develop specific sales capabilities.

\section{LIMITATIONS AND FUTURE RESEARCH}

We identified two limitations. First, the cross-section research strategy restricted us to a specific situation, so we were not able to understand longterm activities, such as the development of customer relationships (Homburg et al., 2015). Thus, an idea for future studies is to develop a longitudinal study to better understand sales activities.

Second, the sales capabilities were divided into personal selling and sales force management. This division provided a more in-depth analysis than previous studies (Krush et al., 2013; Siahtiri et al., 2014), but some activities have not yet been included. So, we suggest extending this concept of sales in future studies in order to include other activities such as sales team training, sales planning, and using control systems (Vorhies \& Morgan, 2005; Baldauf et al., 2001).

\section{CONCLUSION}

The article verified the mediating role of the sales capabilities in Brazilian ICT firms. The results show that sales force management capability mediates the relationship between market orientation and financial performance in both types of companies. Personal selling capability mediates the relationship between market orientation and customer performance in service 
companies. These results add knowledge to previous studies (Guenzi et al., 2016), showing that sales capability needs prior strategic orientation, such as market orientation, with their cultural approach to develop specific capabilities (Narver \& Slater, 1990).

This research allowed us to explore sales capabilities in a more in-depth way. The results emphasize that personal selling and sales force management capabilities do not always evolve in the same way even when influenced by the same orientation, as they are separate specific marketing capabilities (Guenzi et al., 2016). These capabilities depend on the firm's context (Noble et al., 2002).

This study has provided an understanding of the impact of market orientation on sales capabilities, showing that this strategic orientation based on the firm's culture generates market information (Narver \& Slater, 1990). The information is disseminated and worked internally by the different departments to help sales capabilities development (Morgan et al., 2009). When we compare the two kinds of sales capabilities, it turns out that management capability has a greater market orientation impact and a greater influence on financial performance. In other words, these findings show the importance of sales force management capabilities for short-term results, which are mainly financial performance.

\section{CAPACIDADE DE VENDAS E DESEMPENHO: PAPEL DA ORIENTAÇÃO PARA O MERCADO, CAPACIDADES PESSOAIS E GERENCIAIS}

\section{RESUMO}

Objetivo: Explicar a relação entre a capacidade de vendas e a performance financeira e com clientes, em empresas orientadas ao mercado. Essa capacidade é dividida em venda pessoal e gestão da força de vendas, ambas na visão dos gestores.

Originalidade/valor: Esta pesquisa é a primeira que explora em profundidade a capacidade de vendas e demonstra que ela precisa de uma orientação estratégica prévia, além de verificar os diferentes tipos de desempenho que os dois recursos podem resultar. Este estudo ainda é aplicado a dois tipos de empresa, fornecendo várias contribuições para a teoria e prática do marketing. 
Design/metodologia/abordagem: Foi realizado uma survey com 223 empresas divididas de acordo com suas atividades: desenvolvedores de software/serviço e apenas serviços no setor de tecnologia da informação e comunicação (TIC).

Resultados: Primeiro, as capacidades pessoais e gerenciais induzem a desempenhos diferentes, mesmo quando são influenciadas pela mesma orientação estratégica. Segundo, o efeito da mediação reforça que a capacidade de gerenciamento da força de vendas é mais forte que a capacidade de vendas pessoais. Terceiro, nas empresas de serviços, é importante desenvolver uma capacidade de vendas pessoal. Por fim, mostram que as empresas de software/serviços apresentam um comportamento diferenciado das empresas de serviços.

\section{PALAVRAS-CHAVE}

Capacidade de vendas. Vendas pessoal. Gestão da força de vendas. Orientação para o mercado. Performance organizacional.

\section{REFERENCES}

Anderson, E., \& Oliver, R. L. (1987). Perspectives on behavior-based versus outcome-based salesforce control systems. Journal of Marketing, 51 (4), 76-88. doi:10.1177/002224298705100407

Associação Brasileira das Empresas de Tecnologia da Informação e Comunicação (2013). Brasil TI-BPO Book 2013-2015. São Paulo: Brasscom.

Associação Brasileira das Empresas de Tecnologia da Informação e Comunicação (2016). Brasil TI-BPO Book 2015-2016. São Paulo: Brasscom.

Baldauf, A., Cravens, D. W., \& Piercy, N. F. (2001). Examining business strategy, sales management, and salesperson antecedents of sales organization effectiveness. Journal of Personal Selling \& Sales Management, 21 (2), 109-122. doi:10.1080/08853134.2001.10754262

Barney, J. B. (1991). Firm resources and sustained competitive advantage. Journal of Management, 17, 99-120. doi:10.1177/014920639101700108

Chang, W. J. (2014). Market orientation and business-to-business (B2B): A meta-analysis perspective. International Journal of Services Technology and Management, 20(1-3), 123-148. doi:10.1504/ijstm.2014.063569 
Chen, A., Peng, N., \& Hung, K. P. (2015). Managing salespeople strategically when promoting new products-incorporating market orientation into a sales management control framework. Industrial Marketing Management, 51, 141-149. doi:10.1016/j.indmarman.2015.05.006

Cruz-González, J., López-Sáez, P., Navas-López, J. E., \& Delgado-Verde, M. (2015). Open search strategies and firm performance: The different moderating role of technological environmental dynamism. Technovation, 35, 32-45. doi:10.1016/j.technovation.2014.09.001

Day, G. S. (1994). The capabilities of market-driven organizations. The Journal of Marketing, 58(4), 37-52. doi:10.1177/002224299405800404

Deng, S., \& Dart, J. (1994). Measuring market orientation: A multi-factor, multi-item approach. Journal of Marketing Management, 10(8), 725-742. doi:10.1080/0267257x.1994.9964318

Fornell, C., \& Larcker, D. F. (1981). Structural equation models with unobservable variables and measurement error: Algebra and statistics. Journal of Marketing Management, 18(3), 382-388. doi:10.1177/002224378101800313

Guenzi, P., Sajtos, L., \& Troilo, G. (2016). The dual mechanism of sales capabilities in influencing organizational performance. Journal of Business Research, 69(9), 3707-3713. doi:10.1016/j.jbusres.2016.03.033

Guo, C., Wang, Y. J., Hao, A. W., \& Saran, A. (2018). Strategic positioning, timing of entry, and new product performance in business-to-business markets: Do market-oriented firms make better decisions? Journal of Businessto-Business Marketing, 25(1), 51-64. doi:10.1080/1051712x.2018.1424690

Hair, J. F., Hult, G. T. M., Ringle, C. M., Sarstedt, M., \& Thiele, K. O. (2017). Mirror, mirror on the wall: A comparative evaluation of composite-based structural equation modeling methods. Journal of the Academy of Marketing Science, 45(5), 616-632. doi:10.1007/s11747-017-0517-x

Hair Jr., J. F., Hult, G. T. M., Ringle, C., \& Sarstedt, M. (2014). A primer on partial least squares structural equation modeling (PLS-SEM). Thousand Oaks: Sage Publications.

Homburg, C., Vomberg, A., Enke, M., \& Grimm, P. H. (2015). The loss of the marketing department's influence: Is it really happening? And why worry? Journal of the Academy of Marketing Science, 43 (1), 1-13. doi:10.1007/s 11747-014-0416-3

Kirca, A. H., Jayachandran, S., \& Bearden, W. O. (2005). Market orientation: A meta-analytic review and assessment of its antecedents and impact on performance. Journal of Marketing, 69(2), 24-41. doi:10.1509/jmkg.69.2. 24.60761 
Krauss, M. (2005). Marketing dashboards drive better decisions. Marketing News, 39(16), 1.

Krush, M. T., Agnihotri, R., Trainor, K. J., \& Nowlin, E. L. (2013). Enhancing organizational sensemaking: An examination of the interactive effects of sales capabilities and marketing dashboards. Industrial Marketing Management, 42 (5), 824-835. doi:10.1016/j.indmarman.2013.02.017

Kumar, V., Sunder, S., \& Leone, R. P. (2013). Measuring and managing a salesperson's future value to the firm. Journal of Marketing Research, 50(5), 591-608. doi:10.1177/002224371305000515

Lengler, J. F., Sousa, C. M., \& Marques, C. (2013). Exploring the linear and quadratic effects of customer and competitor orientation on export performance. International Marketing Review, 30(5), 440-468. doi:10.1108/IMR03-2011-0087

Lusch, R. F., \& Vargo, S. L. (2006). Service-dominant logic: Reactions, reflections and refinements. Marketing theory, 6(3), 281-288. doi:10.1177/1470 593106066781

Miles, I. (2005). Knowledge intensive business services: Prospects and policies. Foresight, 7(6), 39-63. doi:10.1108/14636680510630939

Mohiuddin Babu, M., Liu, H., Jayawardhena, C., \& Dey, B. L. (2019). Impact of market orientation on firm's customer-based performance: The moderating role of employee orientation. Journal of Marketing Management, 35(7-8), 662-692. doi:10.1080/0267257x.2019.1585928

Morgan, N. A. (2012). Marketing and business performance. Journal of the Academy of Marketing Science, 40(1), 102-119. doi:10.1007/s11747-0110279-9

Morgan, N. A., \& Vorhies, D. W. (2018). The business performance outcomes of market orientation culture and behaviors. In R. Varadarajan \& S. Jayachandran (Eds.). Innovation and strategy (pp. 255-282). Bingley, UK: Emerald.

Morgan, N. A., Vorhies, D. W., \& Mason, C. H. (2009). Market orientation, marketing capabilities, and firm performance. Strategic Management Journal, 30(8), 909-920. doi:10.1002/smj.764

Narver, J. C., \& Slater, S. F. (1990). The effect of a market orientation on business profitability. Journal of Marketing, 54(4), 20-35. doi:10.1177/ 002224299005400403

Ngo, L. V., \& O'Cass, A. (2012). In search of innovation and customerrelated performance superiority: The role of market orientation, marketing capability, and innovation capability interactions. Journal of Product Innovation Management, 29(5), 861-877. doi:10.1111/j.1540-5885.2012.00939.x 
Noble, C. H., Sinha, R. K., \& Kumar, A. (2002). Market orientation and alternative strategic orientations: A longitudinal assessment of performance implications. Journal of Marketing, 66(4), 25-39. doi:10.1509/jmkg. 66.4.25.18513

Pallant, J. (2013). SPSS survival manual. London: McGraw-Hill Education.

Rentz, J. O., Shepherd, C. D., Tashchian, A., Dabholkar, P. A., \& Ladd, R. T. (2002). A measure of selling skill: Scale development and validation. Journal of Personal Selling \& Sales Management, 22 (1), 13-21. doi:10.1080/08853134. 2002.10754289

Rodriguez, M., Ajjan, H., \& Peterson, R. M. (2016). Social media in large sales forces: An empirical study of the impact of sales process capability and relationship performance. Journal of Marketing Theory and Practice, 24(3), 365-379. doi:10.1080/10696679.2016.1170538

Rust, R. T., Ambler, T., Carpenter, G. S., Kumar, V., \& Srivastava, R. K. (2004). Measuring marketing productivity: Current knowledge and future directions. Journal of Marketing, 68(4), 76-89. doi:10.1509/jmkg.68.4. 76.42721

Sawhney, M. (2006). Going beyond the product. In R. F. Lusch \& S. L. Vargo (Eds.). The service-dominant logic of marketing: Dialogue, debate, and directions (pp. 365-380). London: Routledge.

Sharma, A. (2016). What personal selling and sales management recommendations from developed markets are relevant in emerging markets? Journal of Personal Selling \& Sales Management, 36(2), 89-104. doi:10.1080/0 8853134.2016.1185951

Sharma, A., \& Iyer, G. R. (2011). Are pricing policies an impediment to the success of customer solutions? Industrial Marketing Management, 40(5), 723-729. doi:10.1016/j.indmarman.2011.06.002

Siahtiri, V., O'Cass, A., \& Ngo, L. V. (2014). Exploring the roles of marketing and selling capabilities in delivering critical customer centric performance and brand performance outcomes for B2B firms. Journal of Strategic Marketing, 22 (5), 379-395. doi:10.1080/0965254x.2013.876083

Siguaw, J. A., Brown, G., \& Widing, R. E. (1994). The influence of the market orientation of the firm on sales force behavior and attitudes. Journal of Marketing Research, 31 (1), 106-116. doi:10.1177/002224379403100109

Slater, S. F., \& Narver, J. C. (1994). Does competitive environment moderate the market orientation-performance relationship? Journal of Marketing, 58(1), 46-55. doi:10.1177/002224299405800104 
Smirnova, M., Naudé, P., Henneberg, S. C., Mouzas, S., \& Kouchtch, S. P. (2011). The impact of market orientation on the development of relational capabilities and performance outcomes: The case of Russian industrial firms. Industrial Marketing Management, 40(1), 44-53. doi:10.1016/j. indmarman. 2010.09.009

Srivastava, R. K., Fahey, L., \& Christensen, H. K. (2001). The resource-based view and marketing: The role of market-based assets in gaining competitive advantage. Journal of Management, 27(6), 777-802. doi:10.1177/014 920630102700610

Tabachnick, B. G., \& Fidell, L. S. (2013). Using multivariate statistics. London: Pearson.

Teece, D. J., Pisano, G., \& Shuen, A. (1997). Dynamic capabilities and strategic management. Strategic Management Journal, 18(7), 509-533. doi:10. 1002/(sici) 1097-0266(199708) 18:7<509::aid-smj882>3.0.co;2-z

Trott, P. (2008). Innovation management and new product development. London: Pearson.

Vorhies, D. W., \& Morgan, N. A. (2005). Benchmarking marketing capabilities for sustainable competitive advantage. Journal of Marketing, 69(1), 80-94. doi:10.1509/jmkg.69.1.80.55505

Wang, G., \& Miao, C. F. (2015). Effects of sales force market orientation on creativity, innovation implementation, and sales performance. Journal of Business Research, 68(11), 2374-2382. doi:10.1016/j.jbusres.2015.03.041

Weitz, B. A., \& Bradford, K. D. (1999). Personal selling and sales management: A relationship marketing perspective. Journal of the Academy of Marketing Science, 27(2), 241-254. doi:10.1177/0092070399272008

Zoltners, A. A., Sinha, P., \& Lorimer, S. E. (2008). Sales force effectiveness: A framework for researchers and practitioners. Journal of Personal Selling $\mathcal{E}$ Sales Management, 28(2), 115-131. doi:10.2753/pss0885-3134280201

\section{AUTHOR NOTES}

Graziela P. Rodrigues, master from the Postgraduate Program in Administration (PPGADM), Federal University of Paraná (UFPR); Tomas S. Martins, Ph.D. from the Business School, Pontifical Catholic University of Paraná (PUCPR).

Graziela P. Rodrigues is now a Ph.D. student at the Graduate Program in Business Administration (PPGADM) of Federal University of Paraná (UFPR); Tomas S. Martins is now professor at the Business School of Federal University of Paraná (UFPR).

Correspondence concerning this article should be addressed to Graziela P. Rodrigues, Av. Prefeito Lothário Meissner, 632, Jardim Botânico, Curitiba, Paraná, Brasil, CEP 80210-170. E-mail: grazielarodrigues@gmail.com 
EDITORIAL BOARD

Editor-in-chief

Gilberto Perez

Associated Editor

Gisela Demo

Technical Support

Vitória Batista Santos Silva

\section{EDITORIAL PRODUCTION}

Publishing Coordination

Jéssica Dametta

Layout Designer

Emap

\section{Editorial Intern}

Paula Di Sessa Vavlis

Graphic Designer

Libro
Language Editor

Daniel de Almeida Leão 